\title{
Body Fat Percentage of Urban South African Children: Implications for Health and Fitness
}

\author{
DT Goon ${ }^{1}$, AL Toriola ${ }^{2}$, BS Shaw ${ }^{2}$, LO Amusa ${ }^{1}$, LB Khoza ${ }^{3}$, I Shaw ${ }^{2,4}$
}

\begin{abstract}
Objective: To explore gender and racial profiling of percentage body fat of 1136 urban South African children attending public schools in Pretoria Central.

Methods: This is a cross-sectional survey of 1136 randomly selected children (548 boys and 588 girls) aged 9-13 years in urban (Pretoria Central) South Africa. Body mass, stature, skinfolds (subscapular and triceps) were measured. Data were analysed using descriptive statistics (means and standard deviations). Differences in the mean body fat percentage were examined for boys and girls according to their age group/race, using independent t-test samples.

Results: Girls had a significantly $(\mathrm{p}=0.001)$ higher percentage body fat $(22.7 \pm 5.7 \%(95 \% \mathrm{CI}=22.3$, 23.2) compared to boys $(16.1 \pm 7.7 \%, 95 \% \mathrm{CI}=15.5,16.8)$. Percentage body fat fluctuated with age in both boys and girls. Additionally, girls had significantly $(\mathrm{p}=0.001)$ higher percentage body fat measurements at all ages compared to boys. Viewed racially, black children (20.1 \pm 7.5$)$ were significantly $(\mathrm{p}=0.010)$ fatter than white children $(19.0 \pm 7.4)$ with a mean difference of 4.0. Black children were fatter than white children at ages 9, 10, 12 and 13 years, with a significant difference $(\mathrm{p}=0.009)$ observed at age 12 years.

Conclusion: There was a considerably higher level of excessive percentage body fat among school children in Central Pretoria, South Africa, with girls having significantly higher percentage body fat compared to boys. Racially, black children were fatter than white children. The excessive percentage body fat observed among the children in this study has implications for their health and fitness. Therefore, an intervention programme must be instituted in schools to prevent and control possible excessive percentage body fat in this age group.
\end{abstract}

Keywords: Anthropometry, children, percentage body fat, gender and racial differences, South Africa

\section{El Porcentaje de Grasa Corporal en Niños Sudafricanos Urbanos: Implicaciones para la Salud y la Condición Física}

DT Goon ${ }^{1}$, AL Toriola², BS Shaw ${ }^{2}$, LO Amusa ${ }^{1}$, LB Khoza ${ }^{3}$, I Shaw ${ }^{2,4}$

\begin{abstract}
RESUMEN
Objetivo: Explorar la evaluación por perfil de raza y género del porcentaje de grasa corporal de 1136 niños sudafricanos de áreas urbanas, que asisten a escuelas públicas en Pretoria Central.

Métodos: Se trata de un estudio transversal de 1136 niños seleccionados aleatoriamente (548 niños y 588 niñas) de 9-13 años de edad en Sudáfrica urbana (Pretoria Central). Se midieron la masa corporal, la estatura, y los pliegues cutáneos (tríceps y subescapular). Los datos fueron analizados mediante estadística descriptiva (medias y desviaciones estándar). Se examinaron las diferencias en el porcentaje de grasa corporal promedio de niños y niñas según su grupo de edad/raza, utilizando prueba t para muestras independientes.
\end{abstract}

From: ${ }^{1}$ Centre for Biokinetics, Recreation and Sport Science, University of Venda, Thohoyandou, South Africa, ${ }^{2}$ Department of Sports, Rehabilitation and Dental Sciences, Tshwane University of Technology, Pretoria, South Africa, ${ }^{3}$ Dean's Office: School of Health Sciences, University of Venda, Thohoyandou, South Africa and ${ }^{4}$ Office of the Deputy Vice-Chancellor: Research, Monash South Africa, PO Box X60, Ruimsig, 1725, Republic of South Africa.
Correspondence: Dr DT Goon: Centre for Biokinetics, Recreation and Sport Science, University of Venda, X5050 Thohoyandou, Limpopo 0590, Republic of South Africa. E-mail: daniel.goon@univen.ac.za; daniel.goon 2013@yahoo.com 
Resultados: Las niñas presentaban un porcentaje de grasa corporal $(22.7 \pm 5.7 \%, 95 \% C I=22.3,23.2)$ significativamente mayor $(\mathrm{p}=0.001)$ en comparación con los niños $(16.1 \pm 7.7 \%$, 95\% CI $=15.5$, 16.8). El porcentaje de grasa corporal fluctuó con la edad tanto en los niños como en las niñas. Además, las niñas presentaron mediciones de grasa corporal significativamente más altas $(\mathrm{p}=0.001)$ para todas las edades, en comparación con los niños. Racialmente, los niños negros (20.1 \pm 7.5) fueron significativamente $(\mathrm{p}=0.010)$ más gordos que los niños blancos (19.0 \pm 7.4$)$ con una diferencia media de 4.0. Los niños negros eran más gordos que los niños blancos en las edades de 9, 10, 12 y 13 años, con una diferencia significativa $(\mathrm{p}=0.009)$ observada en la edad de 12 años.

Conclusión: Hubo un nivel considerablemente superior de porcentaje de grasa corporal excesiva entre los escolares de Pretoria Central, Sudáfrica, poseyendo las niñas un porcentaje de grasa corporal significativamente mayor que los niños. Racialmente, los niños negros eran más gordos que los niños blancos. El porcentaje de grasa corporal excesiva observada entre los niños de este estudio tiene implicaciones para su salud y su condición física. Por lo tanto, un programa de intervención debe ser instituido en las escuelas para prevenir y controlar posibles excesos en ea porcentaje de grasa corporal en este grupo etario.

Palabras claves: Antropometría, niños, porcentaje de grasa corporal, diferencias de género y raza, Sudáfrica

West Indian Med J 2013; 62 (7): 583

\section{INTRODUCTION}

The proportion of individual fat mass over body weight defines body fat percentage (1). Body fat percentage has been used along with body mass index (BMI) to evaluate human health risks such as cardiovascular risk in clinical practice $(2,3)$. However, because of the inability of BMI to differentiate between body fat and lean mass, its diagnostic performance intermediate ranges of body weight is limited; it cannot accurately categorize individuals who have a normal body weight with too much body fat but too little muscle and those who have an excessive body weight with too little body fat but too much muscle $(4,5)$. A higher body fat percentage might indicate a higher level of cardiovascular risk (1). As obesity has become a serious public health problem affecting both adults and children, it is important to monitor the body composition of children in order to safeguard against future health diseases.

Percentage body fat is regarded as high when exceeding $25 \%$ (for pubertal boys), $>30 \%$ (pre-pubertal children) or $>35 \%$ [for pubertal girls] (6). Conversely, a low percentage body fat of $6-10 \%$ in boys and $12-15 \%$ in girls can adversely affect metabolism and health and it may also indicate diseases, starvation or an eating disorder such as anorexia nervosa (7). It is therefore important to monitor the level of adiposity in children in order to control and prevent health risks associated with excess or low body fatness. Although there are few studies on percentage body fatness of South African children (8-10), the literature assessing the gender and racial profiling of percentage body fat is seemingly scant. Therefore, the purpose of this study was to provide reference data on percentage body fat in a sample of school children in Central Pretoria, aged 9-13 years, and to examine gender and racial profiling of body fatness among the school children.

\section{SUBJECTS AND METHODS}

This study was a cross-sectional survey among primary school children aged 9-13 years attending public schools in Pretoria municipality city, Gauteng province, South Africa. The sampling frame was defined using the enrolment number for each school. This study employed a stratified, two-stage cluster sampling strategy. This procedure ensures adequate representativeness of the study population in the sample. The procedure involved arrangement of study population into schools and class-level clusters. The first stage involved selecting randomly, schools with a probability proportional to the size and enrolment of each school. The second stage involved selecting classes within the participating schools systematically and with equal probability of participation. This afforded all learners in the selected classes the eligibility to participate in the study. Race was determined based on the children's parental background using questionnaire and was categorized as black and white. Participants whose backgrounds did not meet these criteria were excluded from the study. A total of the initial sample of 1286 children was selected to participate in the study. However, due to absenteeism and incomplete data of 150 participants, 1136 participants (548 boys and 588 girls) eventually completed the tests and their data were used in the statistical analysis.

The nature and scope of the study were explained to the children and their parents who gave informed consent. In addition, children who were minors were briefed on the nature and procedures of the study and gave their assent to participate in the study. Approval for the study was given by the Gauteng Department of Education (DoE), Johannesburg, South Africa. The Ethics Committee of Tshwane University of Technology, Pretoria, South Africa, approved the research protocol (Ref: 2008/07/001) before data collection. 
Stature, body mass and skinfolds (triceps, subscapular) were taken according to the standard procedure of the International Society for the Advancement of Kinanthropometry [ISAK] (11). Participants' body mass was measured without shoes and with light clothing to the nearest $0.1 \mathrm{~kg}$, using a digital scale (Tanita-HD 309, Creative Health Products, MI, USA). Their stature was measured to the nearest $0.1 \mathrm{~cm}$ using a mounted stadiometer. Skinfolds were measured to the nearest $0.1 \mathrm{~mm}$ using a Harpenden calliper.

The intra-observer reliability of anthropometric measurements was determined by examining technical error of measurement (TEM) and intraclass correlation coefficient (r) [Pearson's method] (12) based on data obtained from repeated measurements of a small sample of participants $(\mathrm{n}=$ 20). The intraclass correlation coefficients on anthropometric measures between observers were: stature $(0.98)$, body mass (0.97), triceps (0.95) and subscapular (0.94). The reliability coefficients fell within acceptable limits (13).

Percentage body fat $(\% \mathrm{BF})$ was calculated using the skinfold equation of Slaughter et al (14) for predicting body fat in children aged eight to 18 years. The present study utilized the following equations to predict body fat by using triceps (TSKF) and subscapular (SSKF) skinfolds.

(Triceps + Subscapular) $>35 \mathrm{~mm}$ )

Boys: \% Body fat $=0.783$

$(\mathrm{TSKF}+\mathrm{SSKF})+1.6$

Girls: \% Body fat $=0.546$

$(\mathrm{TSKF}+\mathrm{SSKF})+9.7$

(Triceps + Subscapular $)<35 \mathrm{~mm}$ )

Boys: $\%$ Body fat $=1.21(\mathrm{TSKF}+\mathrm{SSKF})$

$-0.008(\mathrm{TSKF}+\mathrm{SSKF})^{2}-1.7$

Girls: $\%$ Body fat $=1.33(\mathrm{TSKF}+\mathrm{SSKF})$

$-0.065(\mathrm{TSKF}+\mathrm{SSKF})^{2}+2.5$
The participants' body fat percentage data were analysed using descriptive statistics, ie means and standard deviations. Differences in the mean body fat percentage were examined for boys and girls according to their age group/race, using independent $t$-test samples. All statistical analyses were conducted with the Statistical Package for the Social Sciences (SPSS), version 18.0 (SPSS, Chicago, IL, USA). A probability level of 0.05 was taken to indicate significance.

\section{RESULTS}

Anthropometric variables were collected from 548 boys $(48.2 \%)$ and $588(51.8 \%)$ girls. Out of the total sample, 581 $(51.1 \%)$ were black and $555(48.9 \%)$ were white children. The mean age of the participants was $11.1 \pm 1.4$ years. The mean ages of boys and girls were $11.3 \pm 1.4$ and $11.0 \pm 1.4$ years, respectively. No significant gender difference was found for age $(p=0.512)$. All the anthropometric measurements were significantly different across gender. The mean values for body mass and skinfolds were significantly $(p=$ $0.001)$ higher in girls compared to boys. Boys were, however, significantly taller compared to girls $[p=0.001]$ (Table 1).

The mean ages of black and white children were 10.8 \pm 1.5 and $11.5 \pm 1.3$ years, respectively. White children were significantly heavier and taller $(p=0.001)$ compared to black children. Conversely, black children had significantly higher mean values of skinfold thickness compared to white children $[p=0.001 ; p<0.05]$ (Table 2).

Girls had a significantly higher percentage body fat compared to boys $(p=0.001)$. The mean percentage body fat for boys was $16.1 \pm 7.7 \%(95 \% \mathrm{CI}=15.5,16.8)$ while the percentage body fat of girls was $22.7 \pm 5.7 \%(95 \% \mathrm{CI}=22.3$,

Table 1: Mean and standard deviation (SD) for anthropometric measurements of South African boys and girls

\begin{tabular}{|c|c|c|c|c|c|}
\hline & Boys $(n=548)$ & Girls $(n=588)$ & Combined $(n=1136)$ & & \\
\hline Variables & Mean \pm SD & Mean \pm SD & Mean \pm SD & $95 \%$ CI & $p$-value \\
\hline Age (years) & $11.3 \pm 1.4$ & $11.0 \pm 1.4$ & $11.1 \pm 1.4$ & $11.0,11.0$ & 0.512 \\
\hline Body mass (kg) & $41.9 \pm 12.0$ & $42.3 \pm 12.1$ & $42.1 \pm 12.0$ & $41.4,42.8$ & $0.001 *$ \\
\hline Stature $(\mathrm{cm})$ & $146.8 \pm 11.1$ & $144.0 \pm 10.6$ & $145.4 \pm 11$ & $144.7,146.0$ & $0.001 *$ \\
\hline Triceps (mm) & $11.2 \pm 5.9$ & $15.1 \pm 5.7$ & $13.2 \pm 6.1$ & $12.8,13.5$ & $0.001 *$ \\
\hline Subscapular (mm) & $8.2 \pm 5.0$ & $13.2 \pm 7.4$ & $10.8 \pm 6.8$ & $10.4,11.2$ & $0.001 *$ \\
\hline
\end{tabular}

*Statistically significant at $p \leq 0.05, \mathrm{CI}=$ confidence interval, $\mathrm{SD}=$ standard deviation

Table 2: Anthropometric characteristics of the participants according to race

\begin{tabular}{|c|c|c|c|c|c|}
\hline & Black $(n=581)$ & White $(\mathrm{n}=\mathbf{5 5 5})$ & Combined $(n=1136)$ & & \\
\hline Variables & Mean \pm SD & Mean \pm SD & Mean \pm SD & $95 \%$ CI & $p$-value \\
\hline Age (years) & $10.8 \pm 1.5$ & $11.5 \pm 1.3$ & $11.1 \pm 1.4$ & $11.0,11.2$ & $0.000 *$ \\
\hline Body mass (kg) & $40.1 \pm 11.1$ & $44.2 \pm 12.4$ & $42.1 \pm 12.0$ & $41.4,42.8$ & $0.001 *$ \\
\hline Stature $(\mathrm{cm})$ & $142.2 \pm 10.2$ & $148.7 \pm 10.6$ & $145.4 \pm 11$ & $144.7,146.0$ & $0.001 *$ \\
\hline Triceps $(\mathrm{mm})$ & $13.9 \pm 6.6$ & $12.4 \pm 5.4$ & $13.2 \pm 6.1$ & $12.8,13.5$ & $0.001 *$ \\
\hline Subscapular (mm) & $11.2 \pm 7.4$ & $10.3 \pm 6.1$ & $10.8 \pm 6.8$ & $10.4,11.2$ & $0.028 *$ \\
\hline
\end{tabular}

*Statistically significant at $p \leq 0.05, \mathrm{CI}=$ confidence interval, $\mathrm{SD}=$ standard deviation 
23.2). Percentage body fat fluctuated with age in both boys and girls. In addition, girls had significantly higher percentage body fat measurements at all ages compared to boys $[p=0.001]$ (Table 3). Shown in Fig. 1 are the differences in percentage body fat in both boys and girls.

\section{DISCUSSION}

Excess percentage body fat constitutes a serious health and physical performance problem. Percentage body fat varies considerably between males and females and between age groups. Usually, males have lower percentage body fat com-

Table 3: Percentage body fat of South African children according to age groups

\begin{tabular}{lrrrrrrr}
\hline & \multicolumn{7}{c}{ Percentage body fat } \\
\cline { 3 - 6 } Age (years) & Boys & Girls & $\begin{array}{c}\text { Boys } \\
\text { (Mean } \pm \text { SD) }\end{array}$ & $\mathbf{9 5 \%}$ CI & $\begin{array}{c}\text { Girls } \\
\text { (Mean } \pm \text { SD) }\end{array}$ & 95\% CI & p-value \\
\hline 9 & 64 & 131 & $17.0 \pm 9.6$ & $14.9,19.7$ & $20.0 \pm 6.4$ & $19.3,21.5$ & $0.001^{*}$ \\
10 & 113 & 138 & $17.8 \pm 6.9$ & $15.9,18.4$ & $20.2 \pm 5.2$ & $19.3,21.1$ & $0.001^{*}$ \\
11 & 88 & 72 & $16.4 \pm 6.2$ & $14.4,17.1$ & $23.5 \pm 6.0$ & $22.0,24.9$ & $0.001^{*}$ \\
12 & 135 & 146 & $17.8 \pm 8.3$ & $15.7,18.5$ & $23.3 \pm 5.5$ & $22.4,24.2$ & $0.001^{*}$ \\
13 & 148 & 101 & $17.8 \pm 7.8$ & $16.3,18.8$ & $24.1 \pm 4.1$ & $23.3,25.0$ & $0.001^{*}$ \\
\hline
\end{tabular}

*Statistically significant $(p \leq 0.05), \mathrm{CI}=$ confidence interval, $\mathrm{SD}=$ standard deviation

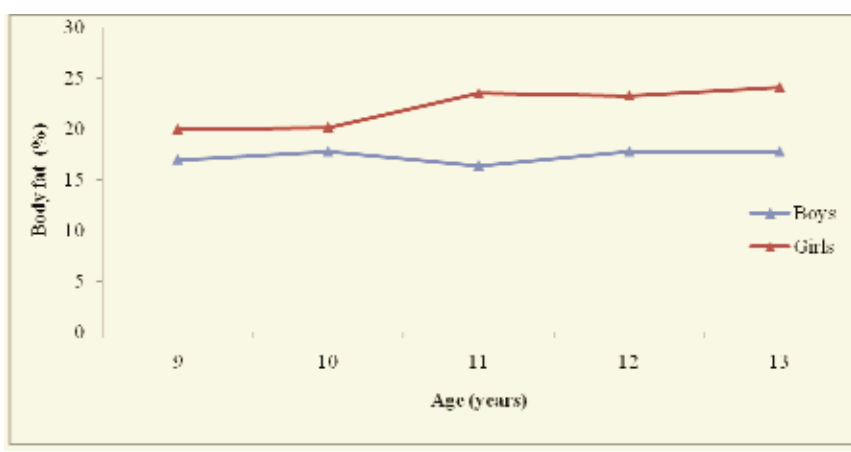

Fig. 1: Age differences in percentage body fat of South African boys and girls.

Viewed racially, black children $(20.1 \pm 7.5)$ were significantly $(p=0.010)$ fatter than white children $(19.0 \pm$ 7.4) with a mean difference of 4.0. Black children were fatter than white children at ages $9,10,12$ and 13 years. However, the difference was significant $(p=0.009)$ only at age 12 years (Table 4). Shown in Fig. 2 is the variation in percentage body fat of black and white children according to age groups.

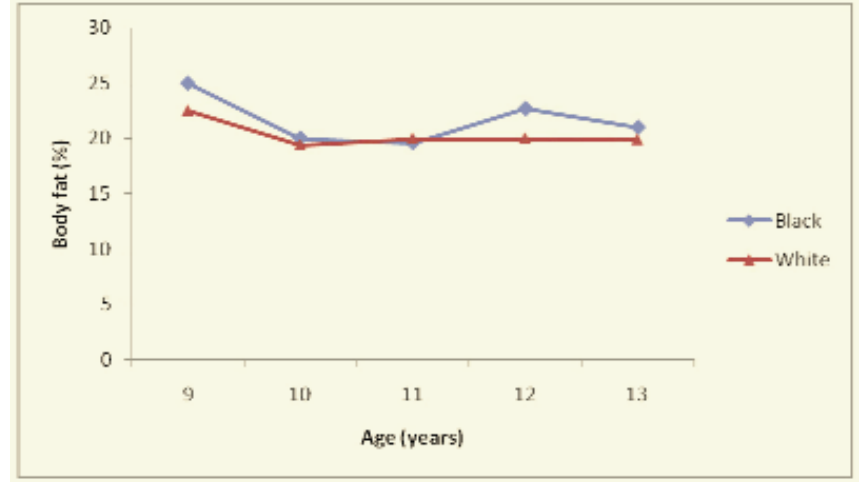

Fig. 2: Age differences in percentage body fat of South African black and white children.

pared to females. The present study demonstrates that percentage body fat is higher in girls $(22.7 \pm 5.7)$ than in boys $(16.1 \pm 7.7)$, and at all ages, that is, $9-13$ years. This sexual dimorphism in adipose tissue in boys and girls is expected and is widely reported in the literature (15-17). Additionally, Mantsena et al (9) in their study of South African children found that girls at ages 5-14 years had higher percentage

Table 4: Percentage body fat of South African children according to race and age groups

\begin{tabular}{|c|c|c|c|c|c|c|c|}
\hline \multirow[b]{2}{*}{ Age (years) } & \multirow[b]{2}{*}{ Black } & \multirow[b]{2}{*}{ White } & \multicolumn{5}{|c|}{ Percentage body fat } \\
\hline & & & $\begin{array}{c}\text { Black } \\
(\text { Mean } \pm \text { SD })\end{array}$ & $95 \% \mathrm{CI}$ & $\begin{array}{c}\text { White } \\
(\text { Mean } \pm \text { SD) }\end{array}$ & $95 \%$ CI & $p$-value \\
\hline 9 & 149 & 46 & $25.0 \pm 10.3$ & $23.3,26.7$ & $22.5 \pm 7.2$ & $20.3,24.6$ & 0.119 \\
\hline 10 & 153 & 98 & $20.0 \pm 6.4$ & $19.0,21.1$ & $19.4 \pm 7.2$ & $17.9,20.8$ & 0.461 \\
\hline 11 & 51 & 109 & $19.6 \pm 7.3$ & $17.5,21.6$ & $20.0 \pm 8.3$ & $18.4,21.5$ & 0.773 \\
\hline 12 & 133 & 148 & $22.7 \pm 8.7$ & $21.2,24.2$ & $20.0 \pm 8.3$ & $18.7,21.4$ & $0.009^{*}$ \\
\hline 13 & 95 & 154 & $21.0 \pm 9.8$ & $19.0,23.0$ & $19.9 \pm 7.7$ & $18.7,21.1$ & 0.308 \\
\hline
\end{tabular}

*Statistically significant $(p \leq 0.05), \mathrm{CI}=$ confidence interval, $\mathrm{SD}=$ standard deviation 
body fat compared to boys. Webster-Gandy et al (18) reported this even as early as 5-7 years among a group of children in Oxford in the United Kingdom. The higher fat accumulation in girls compared to boys might be due to increased physical activity among boys compared to girls (19). The data concerning physical activity and sedentary behaviour among this sample indicate that girls report engaging in less physical activity than boys, spend less time playing electronic games, in computer-related activities, and on watching television (TV) than boys (20). The low physical activity behaviour among girls may be an over-estimation caused by the manner in which the question was framed and the typical physical activities in which girls normally engage. Children participate actively in a variety of ways. Boys are more often engaged in organized sports and competitive teams, and high intensity sports whereas girls spend more time on organized, non-competitive and medium to low intensity sports and exercises.

In South Africa, the socio-economic transformation that has taken place after 18 years of independence has had an impact on nutrition transition and the problem of overnutrition in children seems to exist in different areas. The dietary assessment of these children indicates that they are exposed to high fat intake, thus possibly predisposing them to higher fat accumulation. Data pertaining to dietary food intake of the sample showed high positive loadings on highfat processed foods (ice cream, sweets, hamburgers, chocolate) and snack foods high in fat and/or sugar (such as crisps, crackers, sweet rolls, chocolate, burgers, chips) and fried foods [chips, pizza, hot dogs, boerewors] (20). These food items were first grouped under food component (junk/ unhealthy), accounting substantially for the percentage $(0.44 \%)$ of total variance. Hormonal changes too cannot be ruled out, though this was not evaluated. Girls gain weight and increase body fat percentage at adolescence, due to the stimulation of their sex hormones and the development of their reproductive organs (21). However, one cannot conclusively attribute the increase in body fat percentage found among girls as compared to boys to be indicative of early, sexually diverse changes in body composition that occur during puberty, as maturation was not assessed.

The minimum percentage body fat considered safe and acceptable for good health is 5\% for males and $12 \%$ for females. Adult males have between 15 and $18 \%$ while adult females have between 22 and $25 \%$ (22). In the present study, boys had body fat percentage values of $16.4-20.0 \%$, while girls had 20.2-24.1\% fat content. Considering the age (9-13 years) of the children in the study, these values seem high. As such, the prevalence of excessive weight and obesity reported in these children (20) is not surprising. The high percentage body fat observed among school children in this region is expected from an urban setting where lifestyles and other movement habits/behaviours are 'westernized'. For instance, Western quick-service restaurants seem to have expanded rapidly in South Africa. They are popular among young people, and this might disproportionately increase dietary fat intake in children. Anecdotal as this may appear, it should not be ignored as one of the possible reason for the relatively high body fat seen among this sample in the present study.

It appears South African children are accumulating high percentages of body fat. A similar trend was reported by Monyeki et al (8) among children from Ellisras rural area in Limpopo Province. It could be suggested that the relatively higher percentage body fat among the sample children might be related to the physical inactivity and higher energy intake by these children. Low physical fitness and physical inactivity have been found to be related to many chronic diseases (23) whose occurrence start early in life (24).

This observation has important clinical and public health implications. Too much body fat is detrimental to good health and physical performance. Excessive weight and obesity are two examples of such complications (25). Equally, too little fat (not a case in this study) can also create devastating physiological complications and harmful effects. Low percentage body fat can adversely affect metabolism and health and it may indicate the incidence of disease, malnutrition or an eating disorder such as anorexia nervosa (26).

The racial profiling of percentage body fat of children in this study indicates that black children accumulated more percentage body fat $(20.1 \%)$ than the whites $(19.0 \%)$. These findings are similar to those reported by Daniels et al (27) in which percentage body fat was reported to be higher in black children compared to whites. Contrastingly, although using impedance, the study of Morrison et al (28) found percentage body fat of white children (girls) at 9-12 years to be higher compared to the black children. However, black girls had a greater percentage body fat thereafter. These results agree with white/black differences in body fat levels that have been observed among adults (29) and children (30). The difference observed in the percentage body fat between black and white children in this present study is difficult to explain. However, it is observed that the physical activity and dietary pattern of these two racial groups were also found to be different, and might possibly be responsible for the disparity in percentage body fat found among them. The data reveal that the frequency of participation in physical activity of black children was low compared to whites (20). Besides, the results of the components analysis of the food intake between these two racial groups indicate that the first component (junk/unhealthy food) explained $45.9 \%$ of the total variance in dietary intake among black children, whereas the same (junk/unhealthy food) component had $37.5 \%$ variation among the white children (22). In this regard, the accumulation of more percentage body fat among the black children compared to whites is not surprising. Studies have linked the accumulation of excessive body fat among children to the consumption of unhealthy foods $(31,32)$. With the availability of fast food restaurants and processing food 
industries, it is possible that many South African children eat snack foods such as potato crisps; $40 \%$ eat confectionery and $70 \%$ eat high-fat/sugar based products such as biscuits, cakes, pies, pizza and pastries.

The limitations of this study should be considered. The use of accurate methods of assessing percentage body fat such as underwater weighing, dual-energy X-ray absorptiometry or air replacement plethysmography (33) was not feasible in the present study. Rather, anthropometry (stature, height, skinfolds) was thought to be simple and cost-effective especially in a large sample.

The results of the study cannot be generalized to all South African children, hence the study was limited to children attending primary schools in Central Pretoria. Another limitation of the study was that only school children (black and white) were studied, so that the results of the present study do not necessarily apply to all South African children or other racial groups. These limitations should be considered when interpreting the findings.

\section{CONCLUSION}

In comparison with previous published reports, the present study documents a considerably higher level of excessive percentage body fat in South African school children. Girls had significantly higher percentage body fat compared to boys. Racial profiling indicates that black children accumulate more percentage body fat than white children. This has implications for the children's health and fitness. As such, an intervention programme must be instituted in schools to prevent and control possible excessive percentage body fat in this age group. The children should be encouraged to decrease their consumption of fat and step-up their activity level. Education is the key emphasis. Parents and teachers need to put exercise and nutrition at the forefront. The return of Physical Education in the school curriculum (34) should be effectively implemented in all grades, in order to stimulate regular physical activity. In this regard, concerted efforts should be made at the family, school, community and government levels to promote healthy nutrition and physical activity behaviours in children. The results of this study pertain, of course, to this South African black and white children sample, and it would be helpful to have these results confirmed in other racial groups (Indian and coloured) as well. Future studies examining percentage body fat in these children should endeavour to include cardiovascular risk variables such as total cholesterol, triglycerides, fasting blood glucose, and systolic and diastolic blood pressures. This will aid understanding of the relationship of percentage body fat with physiological variables often associated with increased metabolic risk among South African children. Given the present sample is a cross-sectional sample, these issues could not be addressed here. Therefore, a longitudinal study is warranted.

\section{REFERENCES}

1. Zeng Q, Dong SY, Sun XN, Xie J, Cui Y. Percent body fat is a better predictor of cardiovascular risk factors than body mass index. Braz J Med Biol Res 2012; 45: 591-600. Epub 2012 Apr 19.

2. Imamura Y, Uto H, Oketani M, Hiramine Y, Hosoyamada K, Sho Y et al. Association between changes in body composition and the increasing prevalence of fatty liver in Japanese men. Hepatol Res 2008; 38: $1083-6$.

3. Bandyopahyay A. Anthropometry and body composition in soccer and volleyball players in West Bengal, India. J Physiol Anthropol 2007; 28: 501-5.

4. Romero-Corral A, Somers VK, Sierra-Johnson J, Thomas RJ, CollazoClavell ML, Korinek $\mathrm{J}$ et al. Accuracy of body mass index in diagnosing obesity in the adult general population. Int J Obes $2008 ; \mathbf{3 2}$ : 959-66.

5. Jackson AS, Ellis KJ, McFarlin BK, Sailors MH, Bray MS. Body mass index bias in defining obesity of diverse young adults: the Training Intervention and Genetics of Exercise Response (TIGER) study. Br J Nutr 2009; 102: 1084-94.

6. Westsrate JA, Deurenberg P. Body composition in children: proposal for calculating body fat percentage from density or skinfold thickness measurements. Am J Clin Nutri 1989; 50: 1104-15.

7. Lee DR. Body composition and nutrition assessment. $2^{\text {nd }}$ ed. St Louis: Mosby; 1995.

8. Monyeki KD, Kemper HCG, Makgae PJ. The association of fat patterning with blood pressure in rural South African children: the Ellisras Longitudinal Growth and Health Study. Int J Epidemiol 2006; 35: $114-20$.

9. Mantsena M, Monyeki KD, Toriola AL. Sex differences in percentage body fat of Ellisras children. J Hum Mov Stud 2002; 43: 443-54.

10. Underhay C, De Ridder JH, Van Rooyen JM, Kruger HS. Obesity, blood pressure and physical activity among 10-15 year-old children: the Thusa Bana Study. Afr J Phys Health Edu Recre Dance 2002; 8: 263-84.

11. Marfell-Jones M, Olds T, Stew A, Carter L. International standards for anthropometric assessment. Australia: The International Society for the Advancement of Kinanthropometry, 2006.

12. Malina RM, Hamill PVV, Lemeshow S. Selected measurements of children 6-11 years, United States. Vital and Health Statistics, Series 11, No. 123. Washington, DC: Department of Health and Human Services, US Government Printing Office; 1973.

13. Lohman TG, Roche AF. Martorell R. Anthropometric standardisation reference manual. Champaign, Illinois: Human Kinetics Books; 1988.

14. Slaughter MH, Lohman TG, Boileau RA, Horwill CA, Stillman RJ, Van Loan MD et al. Skinfold equations for estimation of body fatness in children and youth. Hum Biol 1988; 60: 709-23.

15. Ittenbach RF, Buison AM, Stallings VA, Zemel BS. Statistical validation of air-displacement plethysmography for body composition assessment in children. Ann Hum Biol 2006; 33: 187-201.

16. Goon DT, Toriola AL, Shaw BS. Sex differences in body fatness in Nigerian children. Afr J Phys Health Edu Recre Dance 2007; 13: 294-305

17. Ochiai H, Shirasawa T, Nishimura R, Morimoto A, Shimada N, Ohtsu $\mathrm{T}$ et al. Relationship of body mass index to percent body fat and waist circumference among schoolchildren in Japan - the influence of gender and obesity: a population-based cross-sectional study. BMC Public Health 2010; 10: 493.

18. Webster-Gandy J, Warren J, Henry CJK. Sexual dimorphism in fat patterning in a sample of 5 to 7-year-old children in Oxford. Int J Obes 2003; 54: 467-71.

19. Reddy PYB, Rao AP. Nutritional status of pre-school children: Sugali community in Cuddapah district. In: Reddy AR, ed. Health care service management. Hyderabad: Delta Publishing House; 1995: 59-68.

20. Goon DT. A principal components analysis of anatomical fat patterning in South African children [Unpublished D.Tech Thesis]. Pretoria, South Africa: Tshwane University of Technology. 
21. Garnett SP, Hogler W, Blades B. Relation between hormones and body composition, including bone, in prepubertal children. Am J Clin Nutri 2004; 80: 966-72.

22. Quinn E. Body composition and body fat. Sports Medicine Newsletter. [updated 2013 Aug 26; cited 15 May 2006]. Available from: http://sportsmedicine.about.com/od/fitnessevalandassessment/a/Body_ Fat Comp.htm

23. Twisk JWR, Kemper HCC, Van Mechelen W. Prediction of cardiovascular disease risk factors later in life by physical activity and physical fitness in youth. Int J Sports Med 2002; 23: 55-7.

24. Baker DJ. In uteri programming of chronic disease. Clin Sci 1998; 95: $115-28$.

25. Amusa LO, Goon DT, Amey AK. Body composition of South African rural school children aged $7-13$ years: the Tshannda Longitudinal study. Min Pediatr 2011; 63: 263-70.

26. Lohman TG. Body composition assessment in American Indian children. Am J Clin Nutri 1999; 69: 764S-766S.

27. Daniels SR, Khoury PR, Morrison JA. Utility of different measures of body fat distribution in children and adolescents. Am J Epidemiol 2000; 152: $1179-84$

28. Morrison JA, Barton BA, Obarzamck E, Crawford PB, Guo SS, Schreiber GB. Racial differences in the sums of skinfolds and percentage of body fat estimated from impedance in black and white girls, 9 to 19 years of age: the National Heart, Lung, and Blood Institute Growth and Health Study. Obes Res 2001; 9: 297-305.

29. Wagner DR, Heyward VH. Techniques of body composition assessment: a review of laboratory and field methods. Res Q Exer Sports 1999; 70: 135-49.

30. Freedman DS, Wang J, Thornton JC, Mei Z, Pierson RN, Dietz WH et al. Racial/ethnic differences in body fatness among children and adolescents. Obes (Silver Spring) 2008; 16: 1105-11.

31. Ludwig DS, Peterson KE, Gortmaker SL. Relation between consumption of sugar-sweetened drinks and childhood obesity: a prospective, observational analysis. Lancet 2001; 357: 505-8.

32. Bell AC, Kremer PJ, Magarey AM, Swinburn BA. Contribution of 'noncore' foods and beverages to the energy intake and weight status of Australian children. Eur Clin Nutr 2005; 59: 639-45.

33. Jebb SA, Elia M. Techniques for the measurement of body composition: a practical guide. Int J Obes Relat Metab Disord 1993; 17: 611-21.

34. South Africa Department of Education. Life orientation national curriculum statement (grades 10-12): subject assessment guidelines. Pretoria: Author; 2008. 